\title{
ALGORITMA C4.5 UNTUK KLASIFIKASI PEMILIHAN CALON KETUA RW
}

\author{
Erlin Elisa ${ }^{1}$ Rika Harman ${ }^{2}$ \\ Universitas Putera Batam ${ }^{12}$ \\ Jl.R.Suprapto Muka Kuning Batam \\ E-mail : Erlin.Elisa@puterabatam.ac.id ${ }^{1}$, Rika.Harman@puterabatam.ac.id ${ }^{2}$
}

\begin{abstract}
ABSTRAK
Indonesia merupakan sebuah negara yang menjunjung tinggi demokrasi dalam pemerintahannya. Salah satu bentuk demokrasi di Indonesia di adakannya Pemilu (Pemilihan Umum) sekali dalam lima tahun. Pemilihan umum tidak hanya dilakukan pada pemerintahan pusat tetapi juga sampai kepada pemerintahan daerah bahkan pemerintahan ditempat tinggal kita. Keberadaan lembaga masyarakat bertujuan untuk mempercepat masyarakat yang tertib, aman dan sejahtera.Penelitian ini dilakukan untuk mengklasifikasikan kriteria pemilihan calon ketua RW (Rukun Warga) pada sebuah daerah dikota batam, permasalahan yang terjadi selama ini adalah proses pemilihan atau penetapan calon ketua RW belum memiliki kriteria yang harus dijadikan landasan dalam penetapan calon,begitu juga pada saat pemilihan berlangsung para pemilih tidak mengetahui dengan jelas siapa yang dipilih atau mungkin melakukan pemihan atas dasar kenal saja dengan calon, sehingga tujuan sebenarnya diadakan pemungutan suara untuk ketua RW tidak tercapai. Dalam pemilihan partisipasi warga sangat diperlukan akan tetapi tidak semua warga ikut berpartisipasi pada perhelatan ini,tentunya hal ini menimbulkan permasalahan setelah dilakukan pemungutan suara, banyak dari warga yang tidak kenal siapa RW yang terpilih sampai kepada tidak mengetahui latar belakang dari pemimpin diperumahannya, selain itu para calon ketua RW tidak melakukan sosialisasi secara menyeluruh tentang visi-misi kedepan dalam pembangunan masyarakat, situasi ini menimbulkan keluhan dari masyarakat seperti pada saat melakukan pemilihan mereka tidak memilih berdasarkan kriteria yang baik untuk dijadikan wakil pimpinan tempat mereka tinggal. Berdasarkan permasalahan diatas diatas maka peneliti akan menggunakan sebuah teknik datamining dengan algoritma C4.5 yang bertujuan untuk mengklasifikasikan kriteria calon ketua RW (Rukun Warga) sehingga dapat membuat keputusan terhadap penetapan calon RW. Berdasarkan Hasil perhitungan C4.5 dengan pengapliksian decision tree menggunakan aplikasi weka kriteria yang diharapkan oleh masyarakat untuk menjadi calon ketua RW yang akan dipilih dengan nilai gain tertinggi adalah memiliki visi dan misi sebagai calon,mempunyai tingkat solidaritas terhadap tertangga dan memiliki jiwa kepemimpinan yang baik.
\end{abstract}

Kata kunci : Pemilihan,Datamining, Algoritma C4.5 Pohon Keputusan.

\section{ABSTRACTS}

Indonesia is a country that upholds democracy in its government. One form of democracy in Indonesia is to hold an election (General Election) once every five years. Elections are not only carried out at the central government but also to the regional government and even the government where we live. The existence of community institutions aims to accelerate an orderly, safe and prosperous community. This research was conducted to classify the criteria for the selection of candidates for RW (Rukun Warga) candidates in an area in the city of Batam, the problem that has occurred so far is the process of selecting or determining prospective $R W$ heads. which must be used as a basis for determining candidates, as well as voters do not know clearly who is elected or may vote on the basis of just knowing the candidate, so that the actual purpose of voting for the $R W$ chairman is not achieved. In the selection of citizen participation is very necessary but not all residents participate in this event, of course this raises problems after the vote, many of the residents who do not know who the $R W$ is chosen to do not know the background of the leader in their housing, besides the candidates $R W$ chairman did not conduct a comprehensive socialization of the future vision and mission in community development, this situation led to complaints from the community such as when making an election they did not vote based on good 
criteria to be the deputy leader where they lived. Based on the above problems, the researcher will use a data lamination technique with C4.5 algorithm which aims to classify the criteria of prospective $R W$ heads so that they can make decisions about the determination of $R W$ candidates. Based on the results of the C4.5 calculation by applying the decision tree criteria expected by the community to become the candidate for RW leader who will be chosen with the highest gain value is to have a vision and mission as a candidate, have a level of solidarity with the proud and have a good leadership spirit.

\section{Keywords: Selection, Datamining, C4.5 Decision Tree Algorithm.}

\section{PENDAHULUAN}

Demokrasi memiliki pandangan sebagai sesuatu yang penting karena nilai yang terkandung didalamnya sangat diperlukan sebagai acuan dalam kehidupan berbangsa yang baik. Indonesia merupakan sebuah negara yang menjunjung tinggi demokrasi dalam pemerintahannya dimana setiap pembetukan pemerintahan baru dilakukan secara demokrasi melalui pemilihan umum atau yang sering disebut dengan istilah PEMILU.penelitian sebelumnya mengatakan bahwa pemilihan umum merupakan mekanisme utama yang terdapat dalam tahapan penyelenggaraan negara dan pembentukan pemerintahan. Pemilihan umum dipandang sebagai bentuk paling nyata dari kedaulatan yang berada di tangan rakyat dalam penyelenggaraan Negara [1].

Pemilihan umum tidak hanya dilakukan pada pemerintahan pusat seperti pemilihan calon legislatif, presiden kepada tingkat propinsi, daerah saja tetapi ketingkat pemerintahan atau organisasi paling bawah perlu dilakukan pemilihan sebagai wujud terlaksananya suatu kesepakatan yang bernilai demokratis, salah satunya pemerintahan atau organisasi kemasyarakatan tempat tinggal kita.Keberadaan lembaga masyarakat dilingkungan tempat tinggal bertujuan untuk mempercepat masyarakat yang tertib, aman dan sejahtera. Selain itu juga bertujuan untuk meningkatkan potensi masyarakat agar lebih inovatif dan kreatif sehingga dapat berkarya sesuai dengan kemampuan yang dimiliki oleh masyarakat seperti RW (Rukun warga). Rukun Warga (RW) adalah sebuah divisi dari wilayah di Indonesia di bawah Dusun atau Lingkungan. Rukun Warga tidak termasuk Pembagian administrasi pemerintahan, dan pembentukan melewati warga pertemuan. Hal ini dibentuk untuk sosial layanan yang diperbaiki oleh Desa atau Kelurahan. RW terdiri dari beberapa RT [2].

Penelitian ini di lakukan untuk mengklasifikasikan kriteria pemilihan calon ketua RW (Rukun Warga) pada sebuah daerah dikota batam, permasalahan yang terjadi selama ini adalah proses pemilihan atau penetapan calon ketua RW belum memiliki kriteria yang harus dijadikan landasan dalam penetapan calon, begitu juga pada saat pemilihan berlangsung para pemilih tidak mengetahui dengan jelas siapa yang dipilih atau mungkin melakukan pemihan atas dasar kenal saja dengan calon, sehingga tujuan sebenarnya diadakan pemungutan suara untuk ketua RW tidak tercapai. Dalam pemilihan partisipasi warga sangat diperlukan akan tetapi tidak semua warga ikut berpartisipasi pada perhelatan ini tentunya hal ini menimbulkan permasalahan setelah dilakukan pemungutan suara, banyak dari warga yang tidak kenal siapa RW yang terpilih sampai kepada tidak mengetahui latar belakang dari pemimpin diperumahannya, selain itu para calon ketua RW tidak melakukan sosialisasi secara menyeluruh tentang visi-misi kedepan dalam pembangunan masyarakat, situasi ini menimbulkan keluhan dari masyarakat seperti pada saat melakukan pemilihan mereka tidak memilih berdasarkan kriteria yang baik untuk dijadikan wakil pimpinan tempat mereka tinggal.

Datamining akan menggali informasi yang berharga selama ini untuk dijadikan solusi permasalahan kemudian dengan teknik klasifikasi algoritma C4.5 akan menjawab persoalan pada kasus penelitian ini karena Algoritma C4.5 atau pohon keputusan mirip sebuah pohon dimana terdapat node internal (bukan daun) yang mendeskripsikan atributatribut, setiap cabang menggambarkan hasil dari atribut yang diuji, dan setiap daun menggambarkan kelas. Pohon keputusan dengan mudah dapat dikonversi ke aturan klasifikasi [3]. Hasil klasifikasi ini akan menentukan krieria dari calon ketua RW yang layak dipilih oleh warga.

1.1 Knowledge Discovery in Databases (KDD) Menambang data dari sekumpulan data untuk 
menemukan informasi baru yang berguna untuk membuat keputusan bagi perusahaan disebut dengan datamining. Datamining adalah bagian terintegrasi dari Knowledge Discovery Database (KDD), di mana KDD menggambarkan tahapan atau langkah pemrosesan data sebagai penambangan [4].

Untuk lebih jelasnya tahapan dari KDD ini dapat dilihat pada gambar dibawah ini.

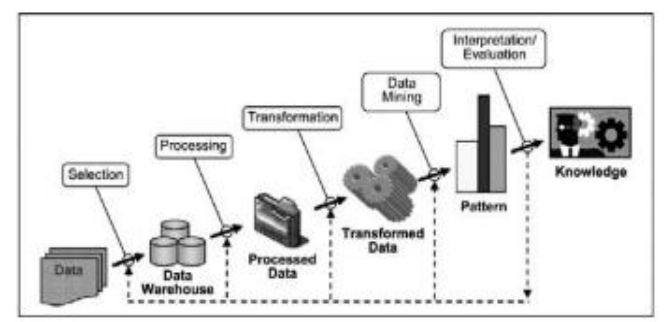

Gambar 1. Proses Knowledge Discovery In Database

\subsection{Datamining}

Pada penelitian sebelumnya untuk megklasifikasi kan resiko kredit mengatakan dalam referensinya bahwa datamining Menurut Gartner Group,data mining adalah proses menemukan hubungan baru yang mempunyai arti, pola dan kebiasaan dengan memilah-milah sebagian besar data yang disimpan dalam media penyimpanan dengan menggunakan teknologi pengenalan pola seperti teknik statistik dan matematika. Datamining merupakan gabungan dari beberapa disiplin ilmu yang menyatukan teknik dari pembelajaran mesin, pengenalan pola, statistik, database, dan visualisasi untuk penanganan permasalahan pengambilan informasi dari database yang besar [5].

Penelitian lain juga mengatakan datamining adalah salah satu cabang ilmu komputer yang banyak menarik perhatian masyarakat. Data mining adalah tumpukan data yang sudah tersimpan selama bertahun-tahun yang dimasukkan kedalam database tetapi tidak digunakan kembali atau disebut "data sampah". Datamining digunakan untuk menggali dan mendapatkan informasi dari data dengan jumlah besar [6].

\subsection{Klasifikasi}

Klasifikasi dapat digambarkan sebagai berikut. Data input, disebut juga training set, terdiri atas banyak contoh (record), yang masing-masing memiliki beberapa atribut. Selanjutnya, tiap contoh diberi sebuah label class khusus teori ini dilakukan pada penelitian sebelumnya untuk memprediksi tingkat kelulusan siswa [7].

Lebih lanjut, input didefinisikan sebagai sekumpulan record (training set), dan setiap record terdiri atas sekumpulan atribut, salah satu atribut adalah klas. Adapun model klasifikasi digunakan untuk antara lain :

1. Pemodelan Deskriptif sebagai perangkat penggambaran untuk membedakan objekobjek dari klas berbeda.

2. Pemodelan Prediktif digunakan untuk memprediksi label klas untuk record yang tidak diketahui atau tidak dikenal [6].

\subsection{Pohon Keputusan}

Manusia selalu dihadapkan dengan berbagai macam masalah dari berbagai bidang kehidupan. Masalah ini juga memiliki variasi tingkat kesulitannya. Untuk menghadapi masalah ini manusia mulai mengembangkan sebuah sistem untuk membantu mereka menyelesaikan masalah-masalah ini, salah satu sistem tersebut adalah pohon keputusan. Pohon keputusan adalah metode klasifikasi dan prediksi yang sudah terbukti powerfull dan sangat terkenal. Metode ini berfungsi untuk mengubah fakta menjadi pohon keputusan yang merepresentasikan aturan yang dapat mudah dimengerti dengan bahasa alami. Proses dari pohon keputusan ini dimulai dari node akar hingga node daun yang dilakukan secara rekursif dimana setiap percabangan menyatakan kondisi dan setiap ujung pohon akan menyatakan keputusan, hal ini diungkap pada penelitian sebelumnya untuk memprediksi calon pegawai baru pada sebuah perusahaan [8].

Penelitian terdahulu dalam referensinya mengatakan Decision tree merupakan metode yang mengubah data menjadi pohon keputusan (decision tree) dan aturan-aturan keputusan [9]. yang dijelaskan pada gambar berikut :

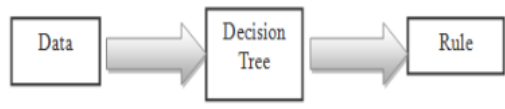

Gambar 2. Konsep Decision Tree

Pada decision tree terdapat 3 jenis node, yaitu:

a. Root node: merupakan node paling atas, pada node ini tidak ada input dan bisa tidak mempunyai output atau mempunyai output lebih dari satu. 
b. Internal node: merupakan node percabangan, pada node ini hanya terdapat satu input dan mempunyai output minimal dua.

c. Leaf node atau terminal node: merupakan node akhir, pada node ini hanya terdapat satu input dan tidak mempunyai output.

\subsection{Algoritma C4.5}

Algoritma C4.5 adalah salah satu metode untuk membuat decision tree berdasarkan training data yang telah disediakan. Beberapa pengembangan yang dilakukan pada $\mathrm{C} 45$ adalah sebagai antara lain bisa mengatasi missing value, bisa mengatasi data kontinu, dan pruning. Algoritma C4.5 diperkenalkan oleh J. Ross Quinlan yang merupakan pengembangan dari algoritma ID3, algoritma tersebut digunakan untuk membentuk pohon keputusan. Pohon keputusan dianggap sebagai salah satu pendekatan yang paling populer, dalam klasifikasi pohon keputusan terdiri dari sebuah node yang membentuk akar, node akar tidak memiliki inputan [10].

Sebuah objek yang diklasifikasikan dalam pohon harus dites nilai Entropy -nya. Entropy adalah ukuran dari teori informasi yang dapat mengetahui karakteristik dari impuryt dan homogenity dari kumpulan data. Dari nilai Entropy tersebut kemudian dihitung nilai information gain (IG) masing-masing atribut. Entropy $(S)$ merupakan jumlah bit yang diperkirakan dibutuhkan untuk dapat mengekstrak suatu kelas (+ atau -) dari sejumlah data acak pada ruang sampel $S$. Entropy dapat dikatakan sebagai kebutuhan bit untuk menyatakan suatu kelas. Semakin kecil nilai Entropy maka akan semakin Entropy digunakan dalam mengekstrak suatu kelas. Entropy digunakan untuk mengukur ketidakaslian $S$.

Untuk memilih atribut akar, didasarkan pada nilai gain tertinggi dari atribut-atribut yang ada. Untuk menghitung gain digunakan rumus seperti yang tertera dalam persamaan berikut.

$\operatorname{Gain}(S, A)=\operatorname{Entropy}(S)-\sum_{i=1}^{n} \frac{|S i|}{|S|} * \operatorname{Entropy}(S i)$

Di mana :

$S \quad$ : himpunan kasus

A : : atribut

$N \quad$ : jumlah partisi atribut $A$
|Si $\quad$ : jumlah kasus pada partisi ke- $i$

$|S| \quad$ : jumlah kasus dalam $S$

Sementara itu, perhitungan nilai entropi dapat dilihat pada persamaan 2 berikut.

$$
\begin{aligned}
& \text { Entropy }(S) \\
& =\sum_{i=1}^{n}-* \log _{2} p i
\end{aligned}
$$

Di mana :

$$
\begin{array}{ll}
S & \text { : himpunan kasus } \\
A & : \text { fitur } \\
N & : \text { jumlah partisi } S \\
\text { pi } & \text { : proporsi dari } S i \text { terhadap } S
\end{array}
$$

\subsection{Weka (Waikato Environment for Knowledge Analysis)}

Waikato Environment for Knowledge Analysis, yang dibuat di Universitas Waikato, New Zealand untuk penelitian, pendidikan dan berbagai aplikasi. Weka mampu menyelesaikan masalah-masalah data mining di dunia nyata, khususnya klasifikasi yang mendasari pendekatan-pendekatan machine learning. Perangkat lunak ini ditulis dalam hirarki class Java dengan metode berorientasi objek dan dapat berjalan hampir di semua platform.Weka mudah digunakan dan diterapkan pada beberapa tingkatan yang berbeda. Tersedia implementasi algoritma-algoritma pembelajaran state-of-theart yang dapat diterapkan pada dataset dari command line. WEKA mengandung tools untuk pre-processing data, klasifikasi, regresi, clustering, aturan asosiasi, dan visualisasi. User dapat melakukan preprocess pada data, memasukkannya dalam sebuah skema pembelajaran, dan menganalisa classifier yang dihasilkan dan performansinya semua itu tanpa menulis kode program sama sekali.Ada banyak metodologi Datamining yang dapat dilakukan pada WEKA, salah satu yang populer adalah pohon keputusan (decision tree).

\section{METODE PENELITIAN \\ 2.1 Metode Pengumpulan Data}

Teknik pengumpulan data dalam analisis klasifikasi pemilihan calon ketua RW adalah sebagai berikut :

\section{Observasi}

Pengumpulan data yang diperoleh dari pengamatan langsung dilapangan tentang permasalahan yang dihadapi dalam penentuan calon ketua RW pada objek penelitian dalam hal ini dilaksanakan pada perumahan cipta asri group dan berbagai aspek yang berhubungan dengan 
penelitian.

2. Studi Literatur

Mempelajari konsep-konsep tentang datamining dengan algoritma C4.5. Sumber literatur dapat berupa buku,jurnal, paper dan website.

3. Wawancara

Untuk mendapatkan data yang akurat diperlukan sebuah tanya jawab dengan daftar pertanyaan yang telah disiapkan dengan pihak-pihak yang terkait dengan objek penelitian.dilakukan untuk mendapatkan data yang tidak diperoleh pada saat observasi lapangan.

2.2 Desain Analisis Penelitian

Desain penelitian ini merupakan langkahlangkah yang akan dilakukan dalam penyelesaian masalah yang akan dibahas. Adapun desain penelitian ini dapat dilihat pada gambar berikut.

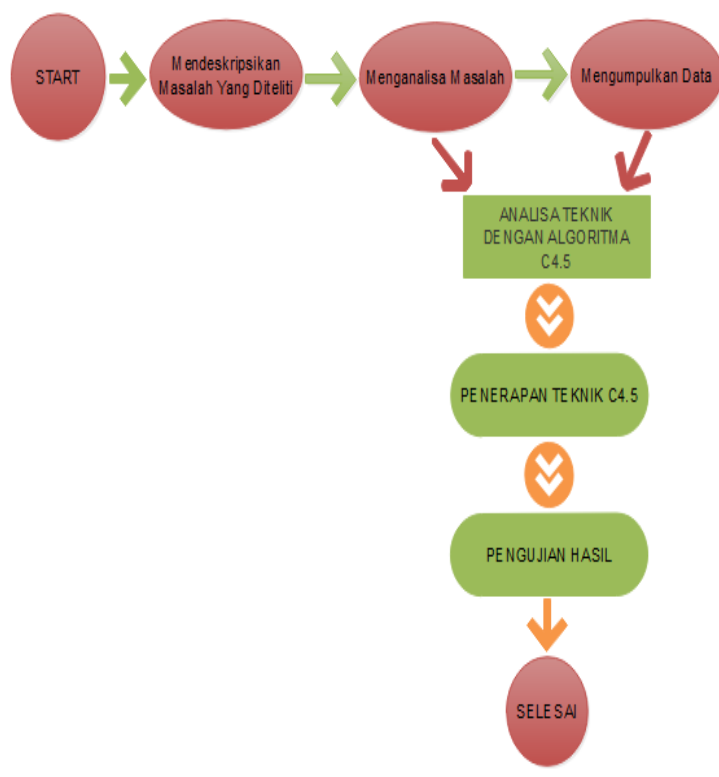

Gambar 3. Desain Penelitian

Berdasarkan desain penelitian pada gambar diatas maka masing-masing langkahnya dapat diuraikan seperti berikut ini :

1. Mendeskripsikan Masalah

Mendeskripsikan masalah yang akan teliti perlu ditentukan terlebih dahulu. Mendeskripsikan masalah dalam penelitian dengan menentukan dan mendefinisikan batasan masalah yang akan diteliti, sehingga membantu dalam mendapatkan suatu solusi yang terbaik dari masalah tersebut. Jadi, langkah pertama ini adalah langkah awal yang terpenting dalam penelitian ini.

2. Analisa Masalah

Langkah analisis masalah merupakan langkah untuk dapat memahami masalah yang telah ditentukan ruang lingkup atau batasannya. Dengan menganalisis masalah yang telah ditentukan tersebut, maka diharapkan masalah dapat dipahami dengan baik.

3. Mempelajari Literatur

Untuk mencapai tujuan, maka dipelajari beberapa literatur-literatur yang diperkirakan dapat digunakan. Kemudian literaturliteratur yang dipelajari tersebut diseleksi untuk dapat ditentukan literatur-literatur mana yang akan digunakan dalam penelitian.

4. Mengumpulkan Data

Dalam pengumpulan data dilakukan observasi yaitu pengamatan secara langsung pada objek penelitian ini sehingga permasalahan yang ada dapat diketahui secara jelas. Kemudian dilakukan interview yang bertujuan untuk mendapatkan informasi atau data yang dibutuhkan. Selain itu juga dilakukan studi kepustakaan yaitu dengan membaca buku-buku yang menunjang dalam melakukan analisis terhadap data dan informasi yang didapat. Analisa teknik pengolahan data menggunakan algoritma C4.5. Data yang diperoleh dari tempat penelitian selanjutnya dilakukan analisa dan pengolahan menggunakan algoritma C4.5.

5. Analisa Teknik Pengolahan Data dengan Algoritma C4.5

Pada tahap ini akan dilakukan proses perancangan dari model sistem dengan algoritma $\mathrm{C} 4.5$ sehingga membentuk pohon keputusan (decision tree) dan menghasilkan suatu rule klasifikasi pemilihan calon Ketua RW.

6. Implementasi Algoritma C4.5

Adapun langkah-langkah dalam tahapan ini adalah :

a. Menentukan atribut sebagai akar dan mengitung nilai informasi gain atribut.

b. Menyusun Tree awal

c. Mengubah Tree menjadi rule

7. Pengujian Hasil

Pada tahap ini, penulis melakukan pengujian dan hasil perancangan sistem menggunakan 
software Data Mining open source WEKA. Sistem diuji dengan prosedur-prosedur untuk melakukan eksplorasi dan permodelan dari data-data yang ada sehingga mendapatkan suatu hubungan tersembunyi dari data tersebut.

\section{HASIL DAN PEMBAHASAN}

3.1 Hasil

Data yang telah dikumpulkan Data yang telah dikumpulkan dan ditransformasikan kedalam bentuk tabel yang akan di mining dengan variabel ukuran berjumlah 6 variabel yaitu : Pendidikan, Peminatan Terhadap Pencalonan, Memiliki Solidaritas Terhadap tetangga/Warga, Memiliki Visi dan Misi Sebagai Calon, Memiliki Jiwa Kepemimpinan, Tanggung Jawab dengan dua tingkat klasifikasi keputusan yaiti Dipilih dan Tidak Dipilih.Kemudian data tersebut akan dimasukan kedalam tabel yang di sebut dengan tabel Pra-proses untuk lebih jelasnya dapat dilihat pada tabel dibawah ini.

Tabel 1. Data Pra-Proses

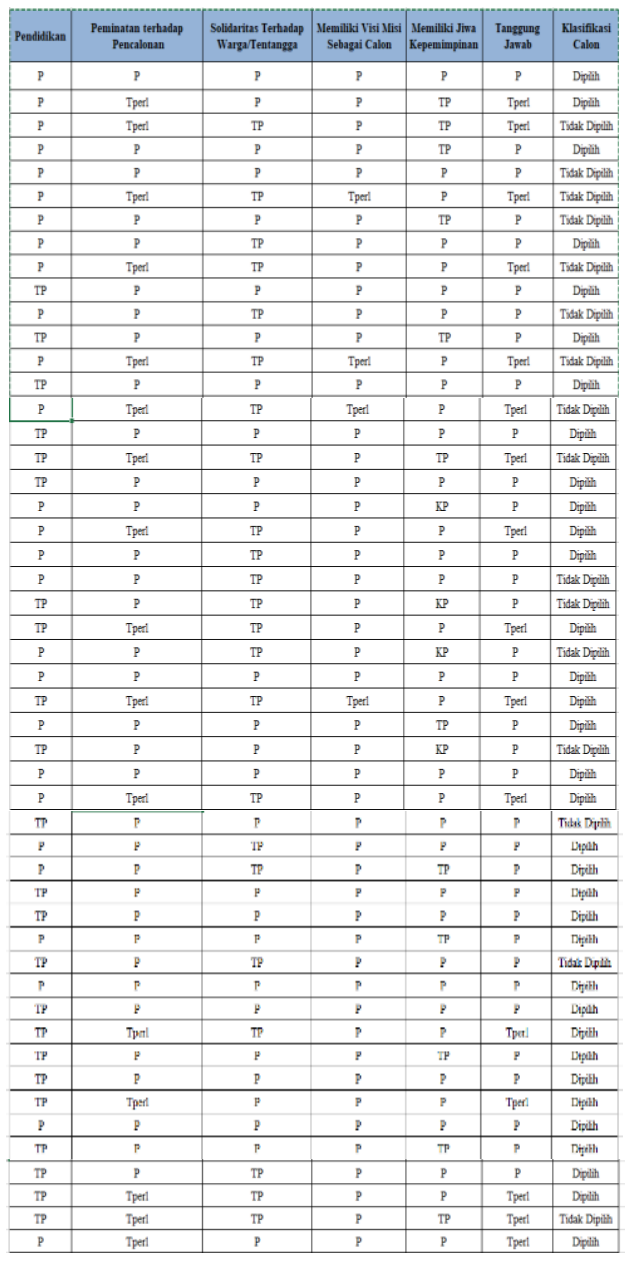

Dari tabel pra-proses diatas maka akan dicari klasifikasi calon ketua RW dengan mencari nilai Entorpy dan Gain masing-masing variabel dengan menggunakan rumus 1 dan 2 pada penjelasan tinjauan pustaka diatas.

1. Nilai Entropy tiap-tiap atribut :

$$
\begin{gathered}
\text { Entropy }(\text { Total })=\left(-\frac{34}{50} * \log _{2}\left(\frac{34}{50}\right)\right)+ \\
\left(-\frac{16}{50} * \log _{2}\left(\frac{16}{50}\right)\right)=0.904381
\end{gathered}
$$

a. Atribut Pendidikan

$$
\begin{gathered}
\text { Entropy }(\text { Penting })=\left(-\frac{17}{27} *\right. \\
\left.\log _{2}\left(\frac{17}{27}\right)\right)+\left(-\frac{10}{27} *\right. \\
\left.\log _{2}\left(\frac{10}{27}\right)\right)=0.95095
\end{gathered}
$$$$
\text { Entropy }(T . \text { Penting })=\left(-\frac{17}{23} *\right.
$$$$
\begin{aligned}
& \left.\log _{2}\left(\frac{17}{23}\right)\right)+\left(-\frac{6}{23} *\right. \\
& \left.\log _{2}\left(\frac{6}{23}\right)\right)=0.82805
\end{aligned}
$$

b. Atribut Peminatan Terhadap Pencalonan

$$
\begin{gathered}
\operatorname{Entropy}(\text { Perlu })=\left(-\frac{25}{34} * \log _{2}\left(\frac{25}{34}\right)\right)+ \\
\left(-\frac{9}{34} * \log _{2}\left(\frac{9}{34}\right)\right)=0.83376 \\
\text { Entropy }(\text { T.Perlu })=\left(-\frac{9}{16} * \log _{2}\left(\frac{9}{16}\right)\right)+ \\
\left(-\frac{7}{16} * \log _{2}\left(\frac{7}{16}\right)\right)=0.98869
\end{gathered}
$$

c. Atribut Memiliki Visi dan Misi Sebagai Calon

$$
\begin{gathered}
\operatorname{Entropy}(\text { Perlu })=\left(-\frac{23}{27} * \log _{2}\left(\frac{23}{27}\right)\right)+ \\
\left(-\frac{4}{27} * \log _{2}\left(\frac{4}{27}\right)\right)=0.60518 \\
\text { Entropy }(\text { T.Perlu })=\left(-\frac{11}{23} * \log _{2}\left(\frac{11}{23}\right)\right)+ \\
\left(-\frac{12}{23} * \log _{2}\left(\frac{12}{23}\right)\right)=0.99863
\end{gathered}
$$

d. Atribut Solidaritas Terhadap Warga

$$
\begin{gathered}
\text { Entropy }(\text { Penting })=\left(-\frac{33}{46} * \log _{2}\left(\frac{33}{46}\right)\right)+ \\
\left(-\frac{13}{46} * \log _{2}\left(\frac{13}{46}\right)\right)=0.85898 \\
\text { Entropy(T.Penting })=\left(-\frac{1}{4} *\right. \\
\left.\log _{2}\left(\frac{1}{4}\right)\right)+\left(-\frac{3}{4} *\right. \\
\left.\log _{2}\left(\frac{3}{4}\right)\right)=0.81127
\end{gathered}
$$


e. Atribut Memiliki Jiwa Kepemimpinan

Entropy $($ Penting $)=\left(-\frac{25}{34} * \log _{2}\left(\frac{25}{34}\right)\right)+$

$$
\left(-\frac{9}{34} * \log _{2}\left(\frac{9}{34}\right)\right)=0.83376
$$

Entropy $($ K.Penting $)=\left(-\frac{1}{4} *\right.$

$$
\begin{aligned}
& \left.\log _{2}\left(\frac{1}{4}\right)\right)+\left(-\frac{3}{4} *\right. \\
& \left.\log _{2}\left(\frac{3}{4}\right)\right)=0.81127
\end{aligned}
$$

Entropy $(T$. Penting $)=\left(-\frac{8}{12} *\right.$

$$
\begin{aligned}
& \left.\log _{2}\left(\frac{8}{12}\right)\right)+\left(-\frac{4}{12} *\right. \\
& \left.\log _{2}\left(\frac{4}{12}\right)\right)=0.91829
\end{aligned}
$$

f. Atribut Tanggung Jawab

$$
\begin{gathered}
\text { Entropy }(\text { Perlu })=\left(-\frac{25}{34} * \log _{2}\left(\frac{25}{34}\right)\right)+ \\
\left(-\frac{9}{34} * \log _{2}\left(\frac{9}{34}\right)\right)=0.83376 \\
\text { Entropy }(\text { T.Perlu })=\left(-\frac{9}{16} * \log _{2}\left(\frac{9}{16}\right)\right)+ \\
\left(-\frac{7}{16} * \log _{2}\left(\frac{7}{16}\right)\right)=0.98869
\end{gathered}
$$

\begin{tabular}{|c|c|c|c|c|c|}
\hline \multirow{2}{*}{$\begin{array}{l}\text { Klasifikasi } \\
\text { Penilaian }\end{array}$} & \multirow{2}{*}{$\begin{array}{c}\text { Jumlah } \\
\text { Kasus }\end{array}$} & \multirow{2}{*}{\begin{tabular}{|c|} 
Dipilih \\
S1
\end{tabular}} & \multirow{2}{*}{\begin{tabular}{|c|} 
Tidak \\
Dipilih
\end{tabular}} & \multirow[t]{2}{*}{ Entropy } & \multirow[t]{2}{*}{ Gain } \\
\hline & & & & & \\
\hline Total & 50 & 34 & 16 & 0.904381458 & \\
\hline \multicolumn{6}{|l|}{ Pendidikan } \\
\hline Penting & 27 & 17 & 10 & 0.950956048 & 0.009959558 \\
\hline Tidak Penting & 23 & 17 & 6 & 0.828055725 & \\
\hline \multicolumn{6}{|l|}{$\begin{array}{l}\text { Peminatan } \\
\text { terhadap } \\
\text { Pencalonan }\end{array}$} \\
\hline Perlu & 34 & 25 & 9 & 0.833764907 & 0.02103751 \\
\hline Tidak Perlu & 16 & 9 & 7 & 0.988699408 & \\
\hline \multicolumn{6}{|l|}{$\begin{array}{l}\text { Memiliki Visi Misi } \\
\text { Sebagai Calon }\end{array}$} \\
\hline Perlu & 27 & 23 & 4 & 0.605186576 & 0.118208163 \\
\hline Tidak Perlu & 23 & 11 & 12 & 0.998635964 & \\
\hline \multicolumn{6}{|l|}{$\begin{array}{l}\text { Solidaritas } \\
\text { Terhadap } \\
\text { Warga/Tentangga }\end{array}$} \\
\hline Penting & 46 & 33 & 13 & 0.858981037 & 0.049216654 \\
\hline Tidak Penting & 4 & 1 & 3 & 0.811278124 & \\
\hline \multicolumn{6}{|l|}{$\begin{array}{l}\text { Memiliki Jiwa } \\
\text { Kepemimpinan }\end{array}$} \\
\hline Pernting & 34 & 25 & 9 & 0.833764907 & 0.052128071 \\
\hline Kurang Penting & 4 & 1 & 3 & 0.811278124 & \\
\hline Tidak Penting & 12 & 8 & 4 & 0.918295834 & \\
\hline \multicolumn{6}{|l|}{ Tanggung Jawab } \\
\hline Perlu & 34 & 25 & 9 & 0.833764907 & 0.02103751 \\
\hline Tidak Perlu & 16 & 9 & 7 & 0.988699408 & \\
\hline
\end{tabular}

Dari perhitungan nilai entropy dan gain diatas dimasukan kedalam tabel sehingga dibentuk tabel nilai node 1.1 sebagai berikut.

Tabel 2. Node 1.1
Dari hasil perhitungan node 1.1 dapat dilihat nilai gain tertinggi berada pada variabel memiliki visi dan misi sebagai calon dimana

\begin{tabular}{|c|c|c|c|c|c|}
\hline \multirow{2}{*}{$\begin{array}{l}\text { Klasifikasi } \\
\text { Penilaian }\end{array}$} & \multirow{2}{*}{$\begin{array}{c}\text { Jumlah } \\
\text { Kasus }\end{array}$} & Dipilih & \multirow{2}{*}{$\begin{array}{l}\text { Tidak } \\
\text { Dipilih } \\
\text { S2 }\end{array}$} & \multirow[t]{2}{*}{ Entropy } & \multirow[t]{2}{*}{ Gain } \\
\hline & & S1 & & & \\
\hline Total & 46 & 33 & 13 & 0.858981037 & \\
\hline Pendidikan & & & & & \\
\hline Penting & 24 & 17 & 7 & 0.870864469 & 0.0003186922 \\
\hline Tidak Penting & 22 & 16 & 6 & 0.845350937 & \\
\hline $\begin{array}{l}\text { Peminatan } \\
\text { terhadap } \\
\text { Pencalonan }\end{array}$ & & & & & \\
\hline Perlu & 34 & 25 & 9 & 0.833764907 & 0.003164584 \\
\hline Tidak Perlu & 12 & 8 & 4 & 0.918295834 & \\
\hline $\begin{array}{l}\text { Solidaritas } \\
\text { Terhadap } \\
\text { Warga/Tentangga }\end{array}$ & & & & & \\
\hline Penting & 27 & 23 & 4 & 0.605186577 & 0.091545073 \\
\hline TidakPenting & 19 & 10 & 9 & 0.998000884 & \\
\hline $\begin{array}{l}\text { Memilliki Jira } \\
\text { Kepemimpinan }\end{array}$ & & & & & \\
\hline Penting & 30 & 24 & 6 & 0.721928095 & 0.078057008 \\
\hline Kurang Penting & 4 & 1 & 3 & 0.811278124 & \\
\hline Tidak Penting & 12 & 8 & 4 & 0.918295834 & \\
\hline Tanggung Jawab & & & & & \\
\hline Perlu & 34 & 25 & 9 & 0.833764907 & 0.003164584 \\
\hline Tidak Perlu & 12 & 8 & 4 & 0.918295834 & \\
\hline
\end{tabular}
nilai gain nya 0.1182082 , sehingga hasil ini menjadikan variabel tersebut menjadi akar pertama dari pohon keputusan, kemudian pencarian akan dilanjutkan lagi dengan perhitungan node 1.2 untuk menetukan akar selanjutnya, hasil perhitungan dapat dilihat pada tabel dibawah ini.

Tabel 3. Node 1.2

Berdasarkan hasil perhitungan Node 1.2 pada tabel diatas dapat dilihat hasil perhitungan Gain tertinggi ada pada variabel solidaritas terhadap tetangga/ warga dengan nilai gain 0.0915451, dengan demikian akar selanjutnya dari pohon keputusan yag terbentuk adalah solidaritas sebagai calon terhadap warga dimana klasifikasi bernilai pernting sudah lebih banyak dari tidak penting sedangkan klasifikasi tidak penting belum dapat diketahui maka akan dilanjutnya dengan perhitungan node 1.3 pada tabel dibawah ini. 
Tabel 4. Node 1.3

\begin{tabular}{|l|c|c|c|c|c|}
\hline \multirow{1}{*}{$\begin{array}{c}\text { Klasifikasi } \\
\text { Penilaian }\end{array}$} & \multirow{2}{*}{$\begin{array}{c}\text { Jumlah } \\
\text { Kasus }\end{array}$} & Dipilih & $\begin{array}{c}\text { Tidak } \\
\text { Dipilih }\end{array}$ & Entropy & Gain \\
\hline & 19 & S1 & S2 & & \\
\hline Total & 10 & 9 & 0.998000884 & \\
\hline & & & & & \\
\hline Pendidikan & & & & & \\
\hline Penting & 11 & 6 & 5 & 0.994030211 & 0.001457077 \\
\hline Tidak Penting & 8 & 4 & 4 & 1 & \\
\hline & & & & & \\
\hline $\begin{array}{l}\text { Peminatan } \\
\text { terhadap } \\
\text { Pencalonan }\end{array}$ & & & & & \\
\hline Perlu & 10 & 5 & 5 & 1 & 0.002228013 \\
\hline Tidak Perlu & 9 & 5 & 4 & 0.99107606 & \\
\hline & & & & & \\
\hline & & & & & \\
\hline $\begin{array}{l}\text { Memiliki Jiwa } \\
\text { Kepemimpinan }\end{array}$ & & & & & \\
\hline Penting & 13 & 9 & 4 & 0.89049164 & 0.217921735 \\
\hline Kurang Penting & 2 & 0 & 2 & & \\
\hline Tidak Penting & 4 & 1 & 3 & 0.811278124 & \\
\hline & & & & & \\
\hline $\begin{array}{l}\text { Tanggung } \\
\text { Jawab }\end{array}$ & & & & & \\
\hline Perlu & 10 & 5 & 5 & & 0.002228013 \\
\hline Tidak Perlu & 9 & 5 & 4 & 0.99107606 & \\
\hline & & & & & \\
\hline
\end{tabular}

Pada tabel node 1.3 ini merupakan perhitugan nilai entropy dan gain terakahir karena telah ditemukan klasifikasi akhir dari pohon keputusan yaitu memiliki jiwa kepemimpinan dengan nilai gain 0.217921735 .

Berdasarkan analisa datamining yang telah dilakukan dengan perhitungan algoritma C4.5 maka didapat hasil bahwasanya klasifikasi untuk kriteria sebagai calon ketua RW yang diinginkan oleh masyarakat sebagai calon yang nantinya mereka pilih adalah :

1. Memiliki Visi dan Misi sebagai calon Setiap calon yang akan memgikuti pemilihan harus memiliki atau penting memiliki visi dan misi yang akan membangun masyarakat kedepannya.

2. Solidaritas Terhadap Warga/Tetangga

Para calon yang akan mengajukan diri dan akan dipilih haruslah orang yang punya solidaritas yang tinggi karena ini merupakan kepala masyarakat tentunya harus memiliki contoh yang baik bagi wargamya.

3. Memiliki Jiwa Kepemimpinan

\subsection{Pembahasan}

Pada pembahasan proses mining yang telah dilakukan pada hasil penelitian ini akan dilakukan pengujian dengan aplikasi weka untuk melihat pohon keputusan yang dibentuk serta menguji kebenaran hasil dari perhitungan manual.
Proses mining dengan weka ini perlu dilakukan transformasi karena weka hanya membaca file yang memiliki format Csv.kemudian akan di explorer ke dalam aplikasi untuk pemilihan variabel yang akan di mining seperti gambar dibawah ini.

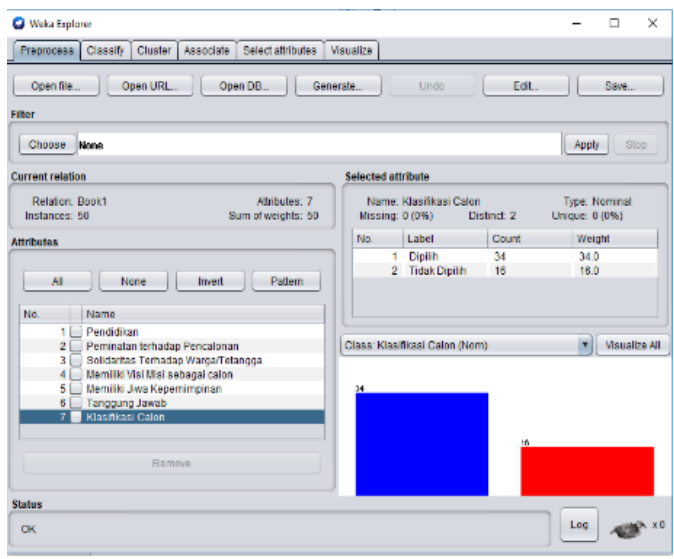

Gambar 4. Pemilihan Variabel Format Data Csv

Dari gambar diatas dapat dilihat klasifikasi dari data yang diperoleh dan dilakukan praproses dalam bentuk format data yang dapat dibaca oleh Weka yaitu terdapat klasifikasi 34 dipilih dan 16 tidak dipilih.

Kemudian dilakukan proses klasifikasi terhadap data yang dimasukkan dengan menggunakan pengklasifikasi (classifier) berupa trees classifier berbasis algoritma J.48, yang merupakan implementasi dari algoritma C4.5 pada WEKA. Untuk lebih jelasnya dapat dilihat pada gambar dibawah ini.

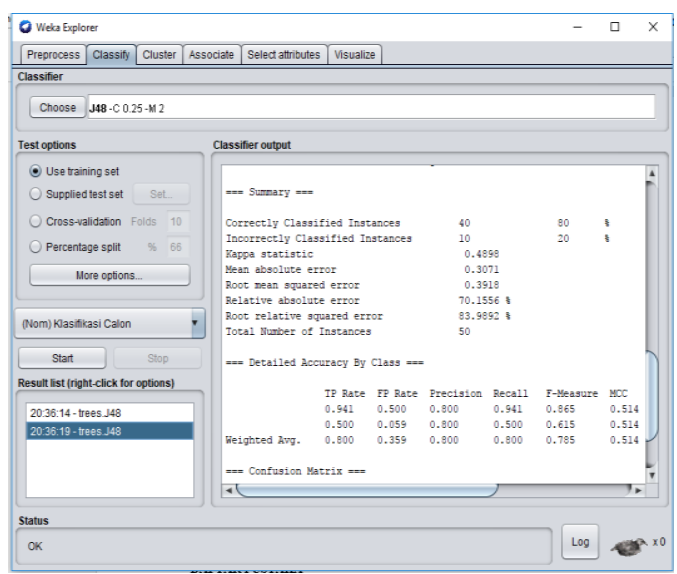

Gambar 5. Using Training Set J4.8 


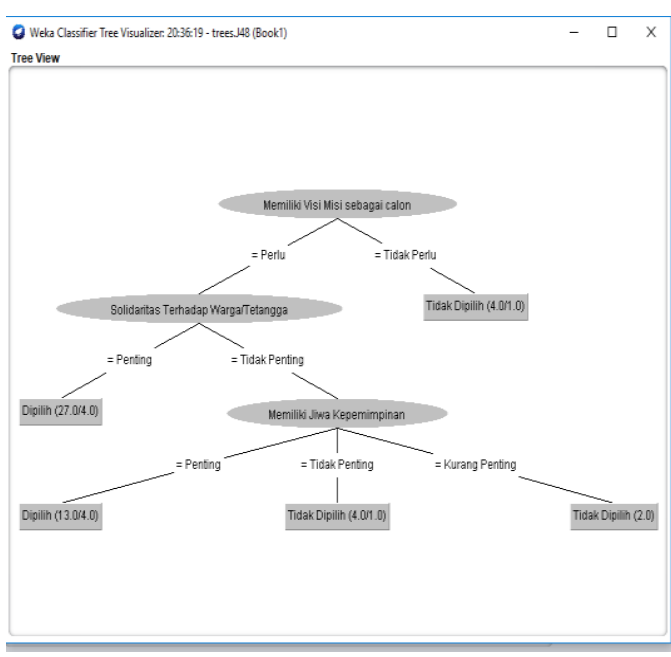

Gambar 6. Pohon Keputusan (Decision Tree)

Dari hasil pohon keputusan yang terbentuk oleh aplikasi weka maka dapat dilihat yang menjadi akar utamanya yaitu memiliki vis dan misi sebagai calon kemudian diikuti solidaritas dan terrakhir memiliki jiwa kepemimpinan hal ini menunjukkan hasil perhitungan manual yang dilakukan sama dengan aplikasi weka.

\section{KESIMPULAN}

4.1 Simpulan

Analisa datamining dengan algoritma C4.5 dapat membantu mengklasifikasikan kriteria Calon Ketua RW yang akan dipilih oleh masyararakat dimana pada hasil pengolahan didapat kriteria dengan nilai gain tertinggi yang menjadi akar pohon keputusan yaitu Calon yang memenuhi kriteria klasifikasi dalam memiliki visi dan mini sebagai calon karena merupakan hal yang penting bagi masyarakat mengenal calonnya memalui visi dan misi yang mereka ajukan untuk menjadi ketua, kemudian memiliki solidaritas yang tinggi terhadap warga sekitar ini merupak sesuatu yang perlu dimiliki oleh sang calon karena pemimpin masyarakat walaupun di tingkat organisasi paling bawah dalam pemerintahan harus memiliki sikap solidaritas terhadap sesama tanpa membeda bedakan suku,agama dan golongan terakhir hasil dari analisa menunjukan seorang calon yang akan dipilih harus masuk dalam kriteria klasifikasi memiliki jiwa kepemimpinan yang baik karena warga butuh seorang calon yang nanti memimpin mereka adalah orang yang bisa mengayomi masyarakat dalam hal kegiatankegiatan berwarga.

Pengujian dengan software weka juga menjelaskan bahwa hasil perhitungan manual dengan software mempunyai kesamaan.

\subsection{SARAN}

Penambahan variabel diperlukan untuk penelitian lebih lanjut baik di lapangan maupun berda,.sarkan data yang ada guna menghasilkan rule yang tepat dan untuk mendapatkan hasil predikasi yang lebih baik perlu menggunakan dan menggabungkan metode klasifikasi yang lain

\section{DAFTAR PUSTAKA}

[1] B. Hardiyanto, Suharso, "Pemilihan Umum Kepala Daerah Periode 2015/2020 (Studi Politik Hukum Calin Tunggal)," vol. 12, no. 1, pp. 204-221, 2016.

[2] Yanuardi, "Pelaksanaan Tugas Rukun Tetanggta dan Rukun Warga (RT/RW) Kelurahan Delima Pekanbaru," vol. 2, no. c, pp. 14, 2015.

[3] H. A. Evicienna, "Algoritma c4.5 Untuk Prediksi Hasil Pemilihan Legislatif DPRD DKI Jakarta," Techno Nusa Mandiri, vol. IX, no. 1, pp. 48-56, 2013.

[4] E. N. Wahyudi, "Teknik Klasifikasi untuk Melihat Kecenderungan Calon Mahasiswa Baru dalam Memilih Jenjang Pendidikan Program Studi di Perguruan Tinggi," vol. 18, no. 1, pp. 55-64, 2013.

[5] Y. Mardi, “Jurnal Edik Informatika Data Mining: Klasifikasi Menggunakan Algoritma C4 . 5 Data mining merupakan bagian dari tahapan proses Knowledge Discovery in Database ( KDD ) . Jurnal Edik Informatika,’ J. Edik Inform., pp. 213-219, 2017.

[6] Eviciana and H. Amalia, "Algoritma C4.5 Untuk Prediksi Hasil Pemilihan Legislatif DPRD DKI Jakarta,' Thecno Nusa Mandiri, vol. IX, no. 1, pp. 48-56, 2013.

[7] G. Indrawan, "Penerapam Metode Decision Tree (Datamining) Untuk Memprediksi Tingkat Kelulusasn Siswa SMPN 1," pp. 35-44, 
2016.

[8] F. F. Harryanto and S. Hansun, "Penerapan Algoritma C4 . 5 untuk Memprediksi Penerimaan Calon Pegawai Baru di PT WISE," Jatisi, vol. 3, no. 2, pp. 95-103, 2017.

[9] T. Thi et al., "Implementasi Iterative Dichotomiser 3 Pada Data Kelulusan Mahasiswa S1 Di Universitas Sebelas Maret," vol. 4, no. 2, pp. 84-91, 2015.

[10] P. A. Sularno, "Penerapan Algoritma C4.5 Untuk Klasifikasi Tingkat Keganasan Hama Pada Tanaman Padi," J. Sains Dan Inform., vol. 2, pp. 54-60, 2016 